\title{
PARTITIONING OF RAINFALL IN EXPERIMENTAL PLANTATIONS OF Eucalyptus urophylla AND Pinus elliottii
}

\author{
Francisco Carlos Soriano Arcova ${ }^{1 *}$, Maurício Ranzini ${ }^{1}$, Valdir de Cicco $^{1}$ \\ ${ }^{1}$ Forestry Institute, Forestry, São Paulo, São Paulo, Brazil - francisco.arcova@ gmail.com*; ranzini@ gmail.com; valdircicco@gmail.com
}

Received for publication: 28/09/2017 - Accepted for publication: 22/03/2018

\begin{abstract}
In a period of 36 months, the partitioning of rainfall was studied in plantations of 30-year-old Eucalyptus urophylla and Pinus elliottii cultivated in flat drainage lysimeters. Gross precipitation was measured with one rain gauge installed in an open area located near the plantations; throughfall was determined by the arithmetic mean of five rain gauges located under the canopy of each species; stemflow was obtained with polyurethane foam collars connected to plastic containers installed on four trees of each species. The mean proportions of throughfall, stemflow and interception in relation to gross rainfall for eucalyptus were $89.0 \%, 5.4 \%$ and $5.6 \%$, respectively, and for pine, they were $79.8 \%, 1.0 \%$ and $19.2 \%$, respectively. The interannual variation in the percentages of interception for the two species had an amplitude of approximately $6 \%$. There was marked variation in the proportion of stemflow depending on the season for eucalyptus, averaging $8.7 \%$ between April and September and 4.6\% from October to March. There was a large number of events with negative interception for eucalyptus. One of the likely causes of the negative interception was capture of fog water by the canopy. Linear regressions estimated that rainfall amounts were responsible for approximately $99 \%$ and $70 \%$ of the variation in throughfall and stemflow, respectively, in the two plantations. Keywords: Interception, throughfall, stemflow, non-native forestry species.
\end{abstract}

\section{Resumo}

Participação da chuva em plantios experimentais de Eucalyptus urophylla e de Pinus elliottii. Num período de 36 meses, a partição da chuva foi estudada em plantios experimentais de Eucalyptus urophylla e de Pinus elliottii com 30 anos de idade cultivados em lisímetros de drenagem planos. A precipitação pluviométrica foi medida com um pluviômetro instalado em área aberta. A transprecipitação foi determinada pela média aritmética de cinco pluviômetros alocados sob o dossel de cada espécie. O escoamento pelo tronco foi obtido com colares de espuma de poliuretano conectados a galões plásticos instalados em quatro árvores de cada plantio. A proporção média da transprecipitação, do escoamento pelo tronco e da interceptação em relação à precipitação pluviométrica para o eucalipto foi de $89,0 \%, 5,4 \%$ e 5,6\% e para o pínus de $79,8 \%, 1,0 \%$ e $19,2 \%$, respectivamente. A variação interanual dos percentuais da interceptação para as duas espécies teve amplitude em torno de seis pontos. Foi observada marcante variação na proporção de escoamento pelo tronco em função da época do ano para o eucalipto, com valor médio de $8,7 \%$ entre abril e setembro e de 4,6\% de outubro a março. Em um grande número de eventos houve interceptação negativa no eucalipto, sendo a captação da água de nevoeiro pelas copas das árvores uma das causas. Regressões lineares estimaram que as quantidades da precipitação pluviométrica foram responsáveis por, aproximadamente, $99 \%$ e $70 \%$ da variação da transprecipitação e do escoamento pelo tronco nos dois plantios, respectivamente.

Palavras-chave: Interceptação, transprecipitação, escoamento pelo tronco, espécies florestais exóticas.

\section{INTRODUCTION}

The area of trees planted for industrial purposes in Brazil totaled 7.8 million hectares in 2015. The plantations of Eucalyptus spp. occupied 5.6 million hectares, representing 71.8\% of the total, and Pinus spp. were spread over 1.6 million hectares, or $20.5 \%$ of the total (IBÁ, 2016). Afforestation with species of these two genera is scattered throughout the country, and there is great concern about the adverse effects these species can cause to the environment, notably in terms of water. In recent years, numerous studies have been carried out to evaluate the hydrological processes associated with different eucalyptus and pine species in very varied silvicultural and environmental conditions (TREVISAN et al., 2012; CALDATO; SCHUMACHER, 2013; SOUZA et al., 2016).

One of the main influences of the forest in the hydrological cycle occurs immediately upon the interaction of rainfall with the canopy of trees, when the water is partitioned into three flows: interception, throughfall and stemflow. This process determines the amount of water that is evaporated while still in the canopy and how much water effectively reaches the forest floor. Partitioning of rainfall is influenced by factors related to vegetation, such as tree height, canopy opening and storage capacity, forest density, branch angle, the uniformity or lack of uniformity in crown height, leaf shape and inclination, leaf area index, species composition, the nature and thickness of the bark

FLORESTA, Curitiba, PR, v. 48, n. 3, p. 383-392, jul/set. 2018

Arcova. F. C. S. et.al.

ISSN eletrônico 1982-4688

DOI: $10.5380 /$ rf.v48i3.55492 
layer, and trunk storage capacity. The process is also conditioned by climatic factors such as quantity, angle, intensity, duration and frequency of rainfall; wind speed and direction during and after rainfall; temperature; and air humidity (CROCKFORD; RICHARDSON, 2000). The presence of epiphytes, lichens and fungi on tree trunks also interferes with water redistribution (SARI et al., 2016).

Rainfall partitioning is the most studied forest hydrological process in Brazil. However, a recent literature review has shown that there is still little research on this subject involving eucalyptus and pine species (GIGLIO; KOBIYAMA, 2013). From nine articles, authors recorded the following ranges of throughfall, stemflow and interception related to rainfall: $71.2 \%$ to $90.4 \%, 1.0 \%$ to $7.4 \%$, and $6.6 \%$ to $21.4 \%$, respectively, in pine plantations; and $78.2 \%$ to $84.0 \%, 1.0 \%$ to $8.1 \%$, and $12.2 \%$ to $15.6 \%$ in eucalyptus plantations, respectively. Studies after this review found values of throughfall, stemflow and interception at $84.0 \%, 1 \%$ and $15.0 \%$, respectively, for $P$. caribaea; $85.2 \%, 1.0 \%$ and $13.8 \%$, respectively, for E. cloeziana (TONELLO et al., 2014); $81 \%, 5 \%$ and 14\%, respectively, for E. urograndis (TREVISAN et al., 2012); and 78.1\%, 11.1\% and $14.6 \%$, respectively, for E. grandis (SARI et al., 2016).

As part of a forest hydrology research project implemented in the upper Vale do Paraíba do Sul in the late 1970s, the Forestry Institute of São Paulo State installed two flat drainage lysimeters to evaluate the water consumption of Eucalyptus urophylla S.T. Blake and Pinus elliottii Engelm. This paper discusses the results of the study on the partitioning of rainfall by the canopies in both species at 30 years of age.

\section{MATERIAL AND METHODS}

\section{Site description}

The research was conducted at the Walter Emmerich Forest Hydrology Laboratory (LHFWE), located in the Cunha nucleus of Serra do Mar State Park (state of São Paulo, Brazil), between the parallels $23^{\circ} 13$ '28 "S and $23^{\circ} 16^{\prime} 10^{\prime \prime} \mathrm{S}$ and meridians $45^{\circ} 02$ '53 "W and $45^{\circ} 05^{\prime} 15^{\prime \prime} \mathrm{W}$, at an altitude of $1,050 \mathrm{~m}$ a.s.1.

The climatic type of the region is $\mathrm{Cwb}$; it is a subtropical highland climate, with rains in the summer and a dry winter. The mean temperature of the hottest month is approximately $22{ }^{\circ} \mathrm{C}$, and the mean temperature of coldest month is approximately $18^{\circ} \mathrm{C}$. The average annual rainfall in the LHFWE is $1,997 \mathrm{~mm}$ (period from 1982 to 2012). The temporal rainfall distribution can be divided into two periods: one characterized as humid, when the events are concentrated and intense (October to March), and one as less humid, when the rains are more uniform, less intense and may extend for several days (April to September). The annual average temperature is $17^{\circ} \mathrm{C}$, and the annual mean relative air humidity is $85.5 \%$.

In the Cunha nucleus, orographic fogs are common resulting from the transport of the humid air of the sea towards the continent by the maritime breeze. Upon encountering the cliff of Serra do Mar, the moist air is forced to rise and condense into droplets, which are propelled by the wind. As a result of these conditions, fog episodes are frequent and may involve the entire LHFWE, which is located $15 \mathrm{~km}$ from the coast.

Additional area information is available in Arcova et al. (2016).

\section{Planting of forest species}

E. urophylla (eucalyptus) and P. elliottii (pine) were planted in two flat drainage lysimeters, consisting of square concrete tanks that were $10 \mathrm{~m}$ wide and $2 \mathrm{~m}$ deep. They were sealed on the bottom, which has a slight slope to one side, concentrating all runoff water to a single outlet through a pipe and directing it to an automatic flow meter. The lysimeters are $20 \mathrm{~m}$ from each other. In 1984, the lysimeters were filled with three distinct substrate layers: $20 \mathrm{~cm}$ of gravel on the bottom, $10 \mathrm{~cm}$ of coarse sand above it, and on the top $150 \mathrm{~cm}$ of soil from the site. In January 1985, a total of 361 seedlings of each species were planted in spacings of $0.5 \times 0.5 \mathrm{~m}$, and three border lines were established in the perimeter of the experimental areas. The plantings were subjected to three thinnings from 1985 to 1995 , with 24 pine trees and 22 eucalyptus trees remaining. In the following years, there were a number of tree deaths due to disease and falls during storms. During the present study, the lysimeters contained 17 pine trees and 13 eucalyptus trees irregularly spaced.

\section{Experimental design and data analysis}

The partitioning of the rainfall in both plantations was determined according to Equation 1:

$$
P=T r+E t+I
$$

In which: P: gross rainfall, which corresponds to the amount of rainfall before reaching the canopy; Tr: throughfall; Et: stemflow; and I: interception. Values are presented in millimeters of water height (mm).

Gross rainfall was measured by a rain gauge (Nakaasa Corporation) that was $20 \mathrm{~cm}$ in diameter and $400 \mathrm{~mm}$ in capacity and was installed $30 \mathrm{~m}$ away from the plantations. For the determination of throughfall, five rain gauges were arranged in each lysimeter. One of the gauges was positioned in the middle of the area, and the 
others were positioned at the vertices of a $4 \times 4 \mathrm{~m}$ square at the center of the lysimeters. The readings were made in graduated cylinders in $\mathrm{mm}$ (Nakaasa Corporation). The stemflow was collected with collars made of polyurethane foam connected by hoses to plastic containers of 40 liter capacity, installed on four trees of each species to contemplate the variation in DBH (diameter at breast height) in each lysimeter.

The amount of water drained by stemflow of all the trees of each planting was estimated from the extrapolation of the sum of the volume collected by the four trees. The conversion of volume ( $\mathrm{mL})$ to millimeters $(\mathrm{mm})$ involved using the area of each lysimeter $\left(100 \mathrm{~m}^{2}\right)$, following a procedure adopted in Cicco et al. (1986/1988). Figure 1 shows the plantations with the water collectors and provides a view from the ground into the sky of the eucalyptus and pine canopy openings.

The interception of each event was calculated by the difference between the gross rainfall and the sum of the mean throughfall of the five pluviometers and the stemflow. Measurements were taken daily between 8:00 AM and 10:00 AM. When the rains lasted more than a day, or occurred on holidays, measurements were taken the next morning. Volumes that accumulated on weekends (Friday after collection, Saturday and Sunday) were measured on the following Monday. When there was overflow of the rain gauges and/or the containers of stemflow, the event was discarded.

The collections were taken from 04/01/2013 to 03/31/2016. To analyze the results, the data were grouped into three twelve-month periods: $04 / 01 / 2013$ to $03 / 31 / 2014,04 / 01 / 2014$ to $03 / 31 / 2015$ and $04 / 01 / 2015$ to $03 / 31 / 2016$.

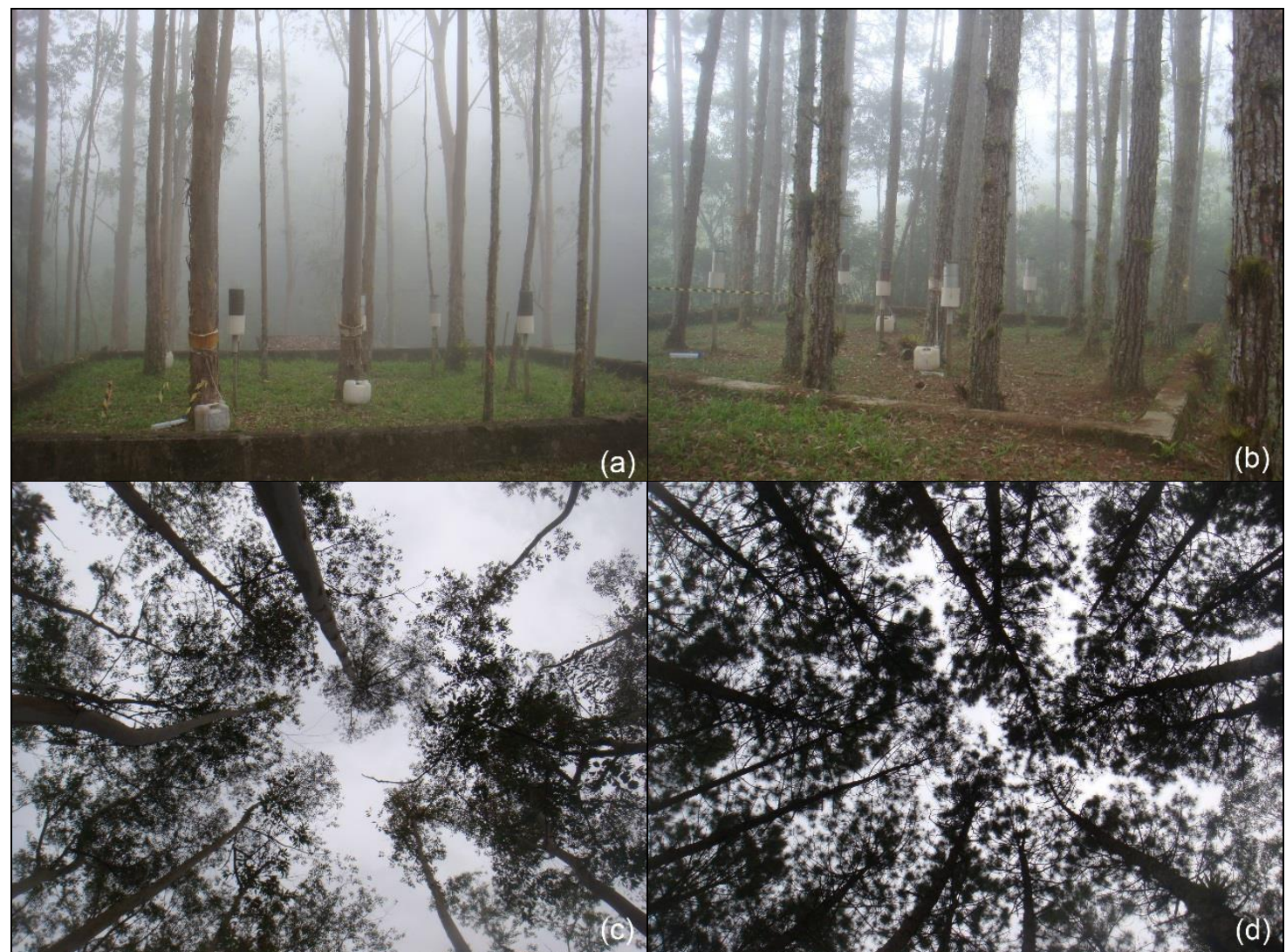

Figure 1. Overview of E. urophylla (a) and P. elliottii (b) plantations; images of E. urophylla (c) and P. elliottii (d) canopies, recorded from the center of the lysimeters.

Figura 1. Vista geral dos plantios de E. urophylla (a) e P. elliottii (b); imagens das copas de E. urophylla (c) e de $P$. elliottii (d), registradas a partir do centro dos lisímetros.

\section{RESULTS}

During the study, data from 415 events were collected. Figure 2 shows the distribution and frequency plots of the various classes of gross rainfall size observed in the three study periods, as well as the mean values of throughfall and stemflow in E. urophylla and P. elliottii.

Table 1 shows the linear regressions that allowed the estimations of the throughfall and stemflow to gross rainfall for the three periods of the study and for the data grouped throughout the experiment, with the respective

FLORESTA, Curitiba, PR, v. 48, n. 3, p. 383-392, jul/set. 2018

Arcova. F. C. S. et.al.

ISSN eletrônico 1982-4688

DOI: $10.5380 /$ rf.v48i3.55492 
coefficients of determination $\left(\mathrm{R}^{2}\right)$. The equations are valid for gross rainfall events in the range of $0.1 \mathrm{~mm}$ to $129.5 \mathrm{~mm}$.

Table 2 presents the components of the partitioning of rainfall totals for both species, as well as the proportions of throughfall, stemflow and interception according to the gross rainfall of each period and a summary for the whole study. The monthly values of throughfall, stemflow and interception in proportion to the gross rainfall for the two species in the three periods are shown in Figure 3

Table 3 shows the mean percentage of throughfall in relation to the gross rainfall as well as the number of events when throughfall exceeded the gross rainfall for the five rain gauges of each planting during the study.
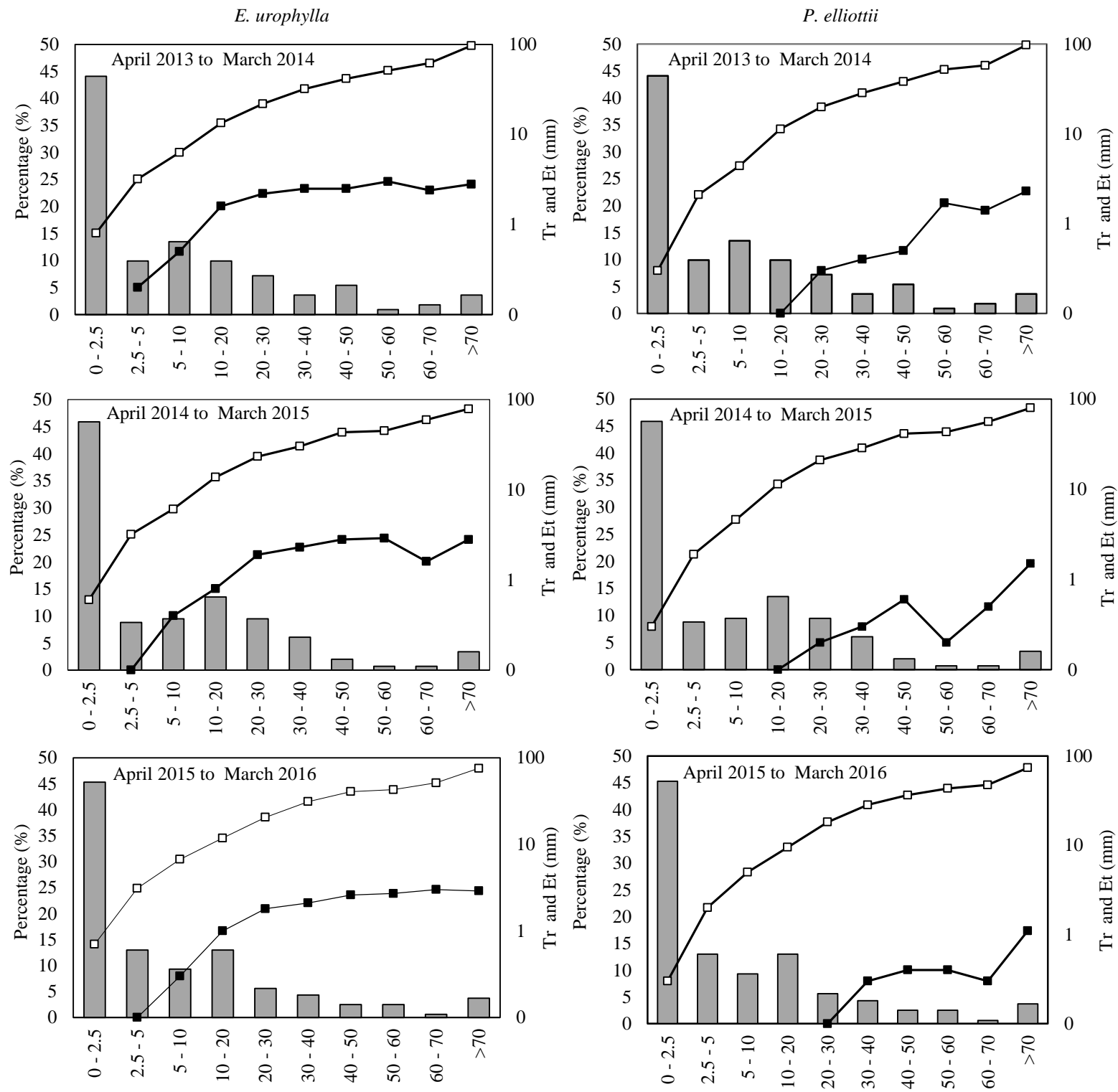

$$
\square \text { Freq. } \rightarrow \text { Average } \operatorname{Tr} \leftarrow \text { Average Et }
$$

Figure 2. Frequency of gross rainfall size classes (\%) and their average values of throughfall (Tr, $\mathrm{mm})$ and stemflow (Et, $\mathrm{mm}$ ) recorded in the E. urophylla and $P$. elliottii plantations.

Figura 2. Frequências das classes de tamanho da precipitação no aberto (\%) e seus respectivos valores médios de transprecipitação (Tr, mm) e escoamento pelo tronco (Et, mm) nos plantios de E. urophylla e P. elliottii.

Table 1. Linear regressions relating gross rainfall $(\mathrm{P})$ with throughfall $(\mathrm{Tr})$ and stemflow (Et) in the E. urophylla and P. elliottii plantations. 
Tabela 1. Regressões lineares relacionando a precipitação no aberto (P) com a transprecipitação (Tr) e com o escoamento pelo tronco (Et) nos plantios de E. urophylla e P. elliottii.

\begin{tabular}{cllll}
\hline \multirow{2}{*}{ Species } & $\begin{array}{l}\text { Apr. 2013 to } \\
\text { Mar. 2014 }\end{array}$ & $\begin{array}{l}\text { Apr. 2014 to } \\
\text { Mar. 2015 }\end{array}$ & $\begin{array}{l}\text { Apr. 2015 to } \\
\text { Mar. 2016 }\end{array}$ & Whole study \\
\hline \multirow{5}{*}{ E. urophylla } & $\mathrm{Tr}=0.913 \mathrm{P}+0.015$ & $\mathrm{Tr}=0.895 \mathrm{P}+0.012$ & $\mathrm{Tr}=0.865 \mathrm{P}+0.007$ & $\mathrm{Tr}=0.891 \mathrm{P}-0.023$ \\
& $\mathrm{R}^{2}=0.9986$ & $\mathrm{R}^{2}=0.9961$ & $\mathrm{R}^{2}=0.9960$ & $\mathrm{R}^{2}=0.9963$ \\
\cline { 2 - 5 } P. elliottii & $\mathrm{E}=0.035 \mathrm{P}+0.365$ & $\mathrm{Et}=0.042 \mathrm{P}+0.136$ & $\mathrm{Et}=0.043 \mathrm{P}+0.113$ & $\mathrm{Et}=0.040 \mathrm{P}+0.190$ \\
& $\mathrm{R}^{2}=0.6139$ & $\mathrm{R}^{2}=0.6911$ & $\mathrm{R}^{2}=0.8011$ & $\mathrm{R}^{2}=0.7012$ \\
\hline & $\mathrm{Tr}=0.908 \mathrm{P}-1.272$ & $\mathrm{Tr}=0.898 \mathrm{P}-1.130$ & $\mathrm{Tr}=0.846 \mathrm{P}-1.049$ & $\mathrm{Tr}=0.883 \mathrm{P}-1.159$ \\
& $\mathrm{R}^{2}=0.9937$ & $\mathrm{R}^{2}=0.9863$ & $\mathrm{R}^{2}=0.9890$ & $\mathrm{R}^{2}=0.9886$ \\
& $\mathrm{Et}=0.020 \mathrm{P}-0.100$ & $\mathrm{Et}=0.016 \mathrm{P}-0.079$ & $\mathrm{Et}=0.011 \mathrm{P}-0.054$ & $\mathrm{Et}=0.016 \mathrm{P}-0.080$ \\
& $\mathrm{R}^{2}=0.8170$ & $\mathrm{R}^{2}=0.6463$ & $\mathrm{R}^{2}=0.6647$ & $\mathrm{R}^{2}=0.6855$ \\
\hline
\end{tabular}

Table 2. Partitioning of rainfall in the E. urophylla and P. elliottii plantations.

Tabela 2. Partição da chuva nos plantios de E. urophylla e P. elliottii.

\begin{tabular}{|c|c|c|c|c|c|c|c|c|}
\hline Period & Species & $\mathbf{P}(\mathbf{m m})$ & $\operatorname{Tr}(\mathbf{m m})$ & Et (mm) & I (mm) & $\operatorname{Tr}(\%)$ & $\operatorname{Et}(\%)$ & I $(\%)$ \\
\hline \multirow{2}{*}{$\begin{array}{l}\text { Apr. } 13 \text { to } \\
\text { Mar. } 14\end{array}$} & E. urophylla & 1562.5 & 1428.6 & 91.2 & 42.7 & 91.43 & 5.84 & 2.73 \\
\hline & P. elliottii & 1562.5 & 1288.8 & 21.4 & 252.3 & 82.48 & 1.37 & 16.15 \\
\hline \multirow{2}{*}{$\begin{array}{l}\text { Apr. } 14 \text { to } \\
\text { Mar. } 15\end{array}$} & E. urophylla & 1863.5 & 1668.3 & 98.1 & 97.1 & 89.53 & 5.26 & 5.21 \\
\hline & P. elliottii & 1863.5 & 1509.8 & 17.5 & 336.2 & 81.02 & 0.94 & 18.04 \\
\hline \multirow{2}{*}{$\begin{array}{l}\text { Apr. } 15 \text { to } \\
\text { Mar. } 16\end{array}$} & E. urophylla & 1972.8 & 1708.7 & 102.7 & 161.4 & 86.61 & 5.21 & 8.18 \\
\hline & P. elliottii & 1972.8 & 1512.1 & 13.1 & 447.6 & 76.65 & 0.66 & 22.69 \\
\hline \multirow{2}{*}{$\begin{array}{l}\text { Whole } \\
\text { study }\end{array}$} & E. urophylla & 5398.8 & 4805.6 & 292.0 & 301.2 & 89.01 & 5.41 & 5.58 \\
\hline & P. elliottii & 5398.8 & 4310.7 & 52.0 & 1036.1 & 79.85 & 0.96 & 19.19 \\
\hline
\end{tabular}



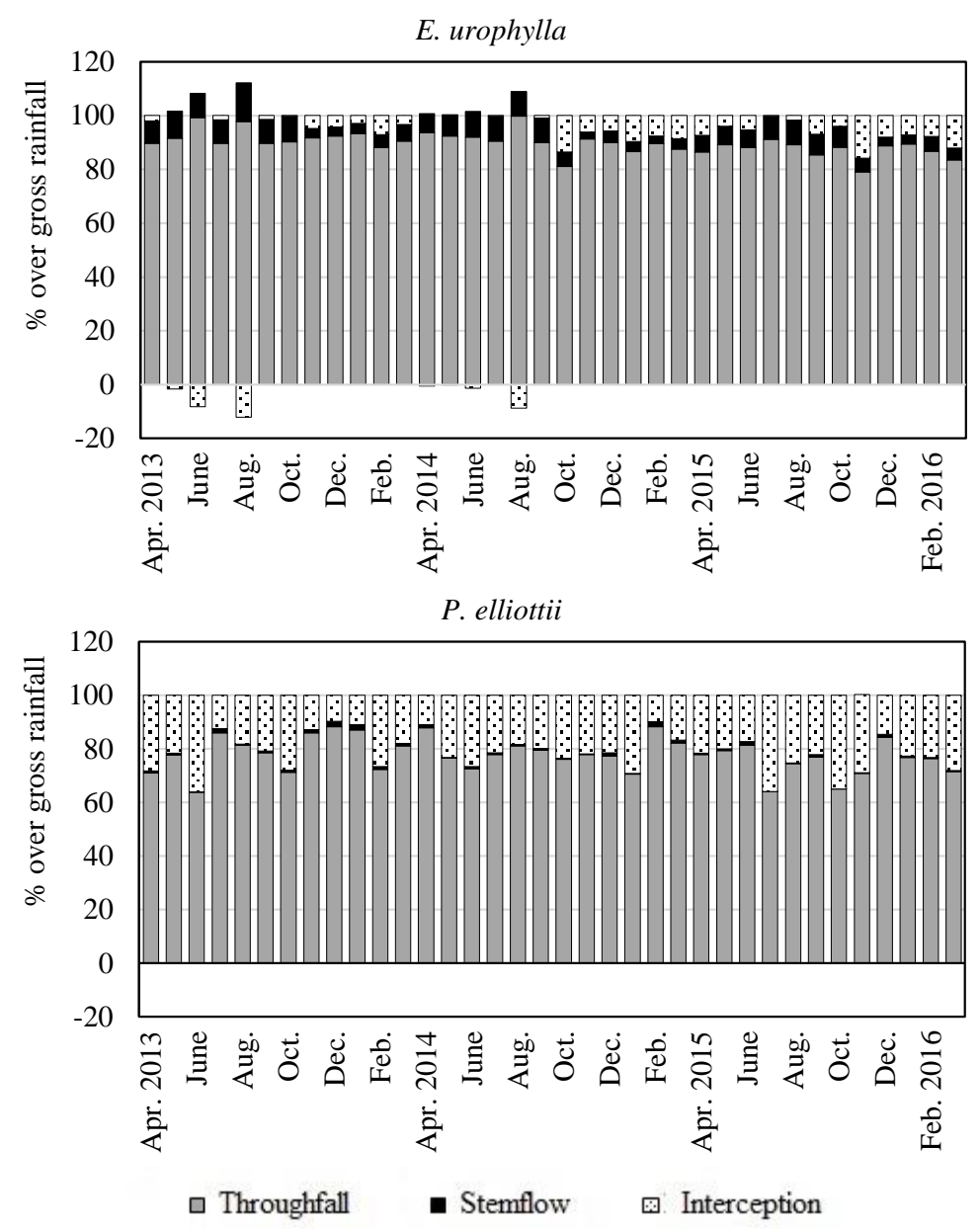

Figure 3. Percent of throughfall, stemflow and interception in relation to gross rainfall in E. urophylla and P. elliottii plantations.

Figura 3. Percentuais de transprecipitação, escoamento pelo tronco e interceptação em relação à precipitação no aberto nos plantios de E. urophylla e P. elliottii.

Table 3. Statistics of throughfall gauges in E. urophylla and P. elliottii plantations.

Tabela 3. Estatísticas dos pluviômetros de transprecipitação nos plantios de E. urophylla e P. elliottii.

\begin{tabular}{ccccc}
\hline \multirow{2}{*}{ Throughfall gauge } & \multicolumn{2}{c}{ E. urophylla } & \multicolumn{2}{c}{ P. elliottii } \\
\cline { 2 - 5 } & $\begin{array}{c}\text { (Tr/P)x100 } \\
\text { mean }\end{array}$ & $\begin{array}{c}\text { Number of events } \\
\text { with } \mathbf{T r}>\mathbf{P}\end{array}$ & $\begin{array}{c}\text { (Tr/P)x100 } \\
\text { mean }\end{array}$ & $\begin{array}{c}\text { Number of events } \\
\text { with } \mathbf{T r}>\mathbf{P}\end{array}$ \\
\hline 1 & 99.8 & 89 & 53.6 & 16 \\
\hline 2 & 108.9 & 171 & 54.8 & 31 \\
\hline 3 & 85.9 & 39 & 60.0 & 6 \\
\hline 4 & 109.7 & 149 & 59.9 & 19 \\
\hline 5 & 81.5 & 32 & 59.9 & 6 \\
\hline
\end{tabular}

\section{DISCUSSION}

The throughfall increased proportionally to the increment of gross rainfall (Figure 2), as verified in plantations of $E$. saligna and P. caribaea (LIMA, 1976). This result occurred even for mild rains but with different magnitudes for both species. For rainfall up to $2.5 \mathrm{~mm}$ (42\% of events), the mean throughfall in the eucalyptus plantation was $0.8 \mathrm{~mm}$ and in the pine plantation was $0.4 \mathrm{~mm}$. Events of $0.1 \mathrm{~mm}$ were enough to generate stemflow 
in the eucalyptus plantation. The reduced leaf cover in this planting allowed the interaction of smaller rains directly with the bark. For the pine plantations, a single episode of $5.6 \mathrm{~mm}$ gross rainfall produced stemflow. For other events, precipitation of more than $10 \mathrm{~mm}$ was required to being the process. Lima (1976) observed that rainfall of less than $2.5 \mathrm{~mm}$ did not cause stemflow in E. saligna and P. caribaea. He also pointed out that to have stemflow in the pine plantation, a greater amount of rainfall was needed than that for eucalyptus. For E. cloeziana and $P$. caribaea, Shinzato et al. (2011) verified the occurrence of stemflow from rainfalls of $6.6 \mathrm{~mm}$ and $8.2 \mathrm{~mm}$, respectively.

The linear regressions of the gross rainfall versus the throughfall were highly significant. The lowest coefficient of determination $\left(\mathrm{R}^{2}\right)$ for eucalyptus was 0.9960 and for pine was 0.9863 . Thus, the amount of gross rainfall was responsible for $99 \%$ of the throughfall variation. The high correlation among these variables has already been documented in the literature (LIMA, 1976; MOURA et al., 2012; GASPAROTO et al., 2014). For stemflow, the $\mathrm{R}^{2}$ values ranged from moderate ( 0.6139 for eucalyptus and 0.6447 for pine) to high ( 0.8011 for eucalyptus and 0.8170 for pine).

In general, gross rainfall was responsible for approximately $70 \%$ of the stemflow variation in both species, a similar result to those found for E. cloeziana $(71 \%)$ and $P$. caribaea (69\%) by Shinzato et al. (2011). The lower influence of gross rainfall on stemflow variation than on throughfall was reported in studies of planted forests and natural forests (LIMA, 1976; MOURA et al., 2012). The equations for estimating stemflow indicate that there are other factors that influence the values of this water flow in addition to the gross rainfall quantity, corroborating Lima (1976).

There was considerable interannual variation in interception percentages, at $5.5 \%$ for eucalyptus and $6.5 \%$ for pine (Table 2). Changes in intensity and duration of rainfall events may have caused this effect (CUARTAS $e t$ al., 2007).

The partitioning of rainfall component proportions in both plantations occurred at considerably different scales. The throughfall in E. urophylla corresponded, on average, to $89.0 \%$ of the gross rainfall, while in P. elliottii, it reached $79.8 \%$. The stemflow was an important water supply path that effectively reached the floor of the eucalyptus plantation, corresponding to $5.4 \%$ of the gross rainfall. For pine, the percentage of gross rainfall reaching the floor was only $1 \%$. Interception in the pine $(19.2 \%)$ was three times greater than in eucalyptus $(5.6 \%)$. The trend of greater interception in conifers than in eucalyptus has already been identified in other studies (GIGLIO, KOBIYAMA, 2013; BENYON; DOODY, 2015).

The mean percentages of throughfall, stemflow, and interception for pine were intermediate to those in studies with species of this genus in Brazil (GIGLIO, KOBIYAMA, 2013, TONELLO et al., 2014). For eucalyptus, interception losses were much lower than the minimum limit of $12 \%$ presented by Giglio and Kobiyama (2013). Additionally, the proportion of gross rainfall converted into stemflow was of the same magnitude as that found in E. urograndis (TREVISAN et al., 2012).

The difference in leaf coverage between both plantations contributed to the wide difference in interception losses. The spaces occupied by the crowns of E. urophylla trees (Figure 1C) occur in lower proportions than those in $P$. elliottii trees (Figure 1D) as a consequence of the lower number of individuals and of flaws in their borders. The percentage of cover that crowns exert above the ground influences interception (TONELLO et al., 2014). Additionally, the heterogeneous development of eucalyptus tree height and diameter contributed to the result.

Stemflow rates are influenced by the dimensional and morphological characteristics of trees. The results obtained in this study are related to, among other factors, the accentuated differences in the characteristics of the bark of both species. P. elliottii bark is thick (between 1 and $3 \mathrm{~cm}$ ), rough and cracked, conditions that provide greater water retention and, consequently, less flow towards the ground. In contrast, E. urophylla presents a thin, smooth, uniform and uncracked bark that facilitates the drainage of water. Similarly, lower leaf cover contributes to the greater stemflow in the eucalyptus, providing greater direct access of the rain to the trunk of the trees (CROCKFORD; RICHARDSON, 2000). Amounts of stemflow are also affected by the presence of epiphytes, lichens and fungi, which attach to the stem (SARI et al., 2016). The water that flows on the trunk can be diverted by these organisms and reach the floor as drops or be stored in these organisms. Bromeliads and lichens are present on almost all pine trees (Figure 1B), unlike eucalyptus (Figure 1A), and contribute for smaller flows of water in the conifer trunk.

Another difference related to stemflow in both plantations is seasonality (Figure 3). There was a marked variation in the proportion of stemflow in eucalyptus with time of year, with an average value of $8.7 \%$ between April and September (cooler months) and 4.6\% from October to March (warmer months). In pine, the average rates of this water flow for the same periods were very close to each other, i.e., $0.7 \%$ and $0.9 \%$, in April to September and October to March, respectively. This difference between the species is related to the effect of bark detachment. P. elliottii bark is persistent and remains permanently fixed to the trunk, a fact that explains the small variation in rates over the months.

FLORESTA, Curitiba, PR, v. 48, n. 3, p. 383-392, jul/set. 2018

Arcova. F. C. S. et.al.

ISSN eletrônico 1982-4688

DOI: $10.5380 /$ rf.v48i3.55492 
In E. urophylla and other species of the same genus, it is common for older layers of the bark (ritidoma) to detach from the trunk as the tree grows in diameter, and this process depends on the season and is more frequent in the hot summer months (FOELKEL, 2006). Pieces of the dead bark may be stuck in the tree for a long time and divert part of the stemflow into throughfall (CROCKFORD; RICHARDSON, 2000). Additionally, from April to September, the rains are more uniform, less intense, and with small droplets and a large inclination and may extend for days in this period, which may contribute to the higher stemflow rates in the eucalyptus for this period. In this condition, the trunks have more access to rainfall (CROCKFORD; RICHARDSON, 2000).

The occurrence of negative interception (when net precipitation exceeds the gross rainfall) was observed in both plantations, but more frequently in E. urophylla (99 events) than in P. elliottii (6 events). In eucalyptus, it culminated in negative values of monthly accumulation in the first months of the periods from April 2013 to March 2014 and April 2014 to March 2015, totaling $10.1 \mathrm{~mm}$ (Figure 3). Negative interception has been reported for a wide range of forest and climate types and may be a consequence of underestimating gross precipitation or overestimating throughfall (CROCKFORD; RICHARDSON, 2000). In this study, the underestimation of the water intake was not a determining factor since pine had negligible negative interception even though it was only twenty meters from the eucalyptus plantation.

The overestimation of throughfall has been recorded in natural forests (MOURA et al., 2012) and planted forests (GASPAROTO et al., 2014). This phenomenon usually results from the installation of rain gauges in places where the canopy provides conditions for the concentration of rainwater and the direction of the drip for these collectors. Two of the five rain gauges installed under eucalyptus presented mean throughfall percentages of $110 \%$ in relation to the gross rainfall, one showed $100 \%$, and the others presented values lower than $100 \%$. The first three rain gauges were installed near the tallest tree, whose tree top passed the canopy ceiling. In this circumstance, trees tend to be more efficient in catching inclined rains than neighboring trees (more sheltered) and have the potential to generate throughfall higher than gross rainfall (HERWITZ; SLYE, 1992).

Another situation that can result in high throughfall is branch intertwinement in the canopy, creating preferential paths of conduction and water drip (TONELLO et al., 2014). The structure of the eucalyptus canopy is quite heterogeneous, with trees of different sizes and overlapping of crowns that can create these paths and influence the rates of throughfall. In the rain gauges installed under the pine, few rain events had negative interceptions. In addition, the percentage relationship between throughfall and gross rainfall did not exceed $60 \%$ (Table 3), reflecting homogeneity among the trees in terms of height, diameter and shape and size of the crowns. Thus, in the pine plantation, there were not the previously mentioned conjectures for overestimating throughfall.

In sites with frequent fog, such as Cunha, net precipitation can also overcome rainfall as a result of occult precipitation, i.e., capture and dripping of water from the fog through the treetops (GOMEZ-PERALTA et al., 2008; PRADA et al., 2012). An indication of the occurrence of occult precipitation in eucalyptus is the fact that of the 415 events recorded during the study, throughfall water was collected without the presence of gross precipitation on 16 occasions, totaling $3.7 \mathrm{~mm}$. This low value is derived from the fact that when occult precipitation occurs without the presence of rain, small droplets from fog water saturate the canopies, condense and form larger droplets that detach from leaves or seep through the trunk by the action of gravity.

However, a study conducted in Cunha showed that fog is often associated with orographic rainfall (ARCOVA et al., 2016). In this condition, the occult precipitation tends to be greater than that coming from events without gross rainfall since fog does not need to saturate the canopy once rain has. It is possible that part of the 99 events with negative interception originated from situations similar to this.

At least three factors corroborated occult precipitation in eucalyptus and not in pine: exposure to fog, canopy height, and wind speed. The exposure of the plantations to the fog is a determining factor. Field observations over three years have shown that the main flow of orographic fogs in LHFWE occurs through experimental catchment $\mathrm{D}$, from the headwaters to the outlet of the watercourse (ARCOVA et al., 2016). The lysimeter in eucalyptus is located next to the outlet of catchment D, thus covered entirely by fogs. However, the lysimeter in pine is situated behind the eucalyptus plantation, positioned in its "shade", a circumstance that provides less interaction of the trees with drops of water suspended in the air.

The height of the trees should also have contributed to the difference found between the plantations. The eucalyptus canopy is approximately five meters higher than the pine canopy and tends to capture more water. Although no anemometric measurements were taken in the present study, during field observations it was observed that the crowns of eucalyptus trees were more susceptible to wind action than pine trees. The movement of the leaves and branches is essential for the dripping of intercepted fog water (PRADA et al., 2012).

A study on the hydrological potential of fog in the LHFWE showed that, despite the high incidence of this meteorological phenomenon in Cunha, water collection by the fog collectors especially constructed for this purpose was reduced. In addition, it was verified that occult precipitation in experimental catchment D covered with Atlantic Forest occurred at insignificant amounts due to the low speed of the winds, the short duration of the fog episodes and the arrangement of the catchment in relation to the main flows of the fog, i.e., leeward (opposite

FLORESTA, Curitiba, PR, v. 48, n. 3, p. 383-392, jul/set. 2018 
to the wind), which is not the most auspicious for the generation of occult precipitation. It was inferred in the present research that the potential of eucalyptus planting to generate occult precipitation is the result of its better location in relation to the wide exposure of the trees to the fog and the winds. In addition, the morphological characteristics of the species also contribute with the surfaces of their branches, trunks and leaves being smooth and providing greater drainage of the captured fog water. Moreover, the orientation of the leaves, leaning and facing down, facilitates dripping through the canopy. Additionally, 55\% of the events with throughfall higher than gross precipitation occurred with rains equal to or less than $2.5 \mathrm{~mm}$. In Cunha, these mild rains are often accompanied by fog.

\section{CONCLUSIONS}

The analyses of the results of rainfall partitioning during the 36-month collection period allow us to conclude the following:

- The mean throughfall, stemflow and interception in relation to gross precipitation were $89.0 \%, 5.4 \%$ and 5.6\%, respectively, for Eucalyptus urophylla and 79.8\%, 1.0\% and 19.2\% for Pinus elliottii, respectively. These numbers are consistent with those found in studies of species for both genera in Brazil, with the exception of eucalyptus interception, which was considerably smaller.

- Eucalyptus stemflow was highlighted by the observed seasonality patterns, with rates almost twice as high in the months from April to September compared to the period from October to March. This behavior is related to the peeling effect of the trunk bark of this species throughout the year.

- There were considerable events with negative interception in the eucalyptus plantation. The factors likely related to these occurrences were the overestimation of throughfall in the rain gauges installed at rainwater concentration points beneath the canopy and the occult precipitation resulting from the capture of fog water from the tree canopy.

- The linear equations that related the throughfall and stemflow with gross rainfall presented very good correlations.

\section{REFERENCES}

ARCOVA, F. C. S.; GALVANI, E.; RANZINI, M.; CICCO, V. Ocorrência de nevoeiros em uma microbacia experimental na Serra do Mar, Cunha, SP. Revista Brasileira de Climatologia, Curitiba, v. 18, p. 327 - $348,2016$.

BENYON; R. G.; DOODY, T. M. Comparison of interception, forest floor evaporation and transpiration in Pinus radiata and Eucalyptus globulus plantations. Hydrological Processes, Amsterdam, v. 29, n. 6, p. 1173 - 1187 , 2015.

CALDATO, S. L.; SCHUMACHER, M. V. O uso de água pelas plantações florestais-uma revisão. Ciência Florestal, Santa Maria, v. 23, n. 3, p. 507 - 516, 2013.

CROCKFORD, R. H.; RICHARDSON, D. P. Partitioning of rainfall into throughfall, stemflow and interception: effect of forest type, ground cover and climate. Hydrological Processes, Amsterdam, v. 14, n. 16 - 17, p. 2903 2920, 2000.

CICCO, V.; ARCOVA, F. C. S.; SCHIMOMICH, P. Y.; FUJIEDA, M. Interceptação das chuvas por floresta natural secundária de Mata Atlântica - São Paulo. Silvicultura em São Paulo, São Paulo, v. 20/22, p. 25-30, $1986 / 88$.

CUARTAS, L. A.; TOMASELlA, J.; NOBRE, A. D.; HODNETT, M. G.; WATERLOO, M. J.; MÚNERA, J. C. Interception water-partitioning dynamics for a pristine rainforest in Central Amazonia: Marked differences between normal and dry years. Agricultural and Forest Meteorology, Amsterdam, v. 145, n. 1 - 2, p. 69 - 83, 2007.

FOELKEL, C. Casca da árvore do eucalipto: aspectos morfológicos, fisiológicos, florestais, ecológicos e industriais visando a produção de celulose e papel. Porto Alegre: Eucalyptus Online Book, 2006. Disponível em: <http://www.eucalyptus.com.br/capitulos/capitulo_casca.pdf>. Acesso em: 01 set. 2016.

GASPAROTO, E. A. G.; TONELlO, K. C.; SHINZATO, E. T.; VALENTE; R. O. A. Throughfall in different forest stands of Iperó, São Paulo. Cerne, Lavras, v. 20, n. 2, p. 303 - 310, 2014.

GIGLIO, J. N.; KOBIYAMA, M. Interceptação da chuva: uma revisão com ênfase no monitoramento em florestas brasileiras. Revista Brasileira de Recursos Hídricos, Porto Alegre, v. 18, n. 2, p. 297 - 317, 2013.

FLORESTA, Curitiba, PR, v. 48, n. 3, p. 383-392, jul/set. 2018

Arcova. F. C. S. et.al.

ISSN eletrônico 1982-4688

DOI: $10.5380 /$ rf.v48i3.55492 
GOMEZ-PERALTA, D.; OBERBAUER, S. F.; MCCLAIN, M. E.; PHILIPPI, T. E. Rainfall and cloud-water interception in tropical montane forests in the eastern Andes of Central Peru. Forest Ecology and Management, Amsterdam, v. 255, n. 3 - 4, p. 1315 - 1325, 2008.

HERWITZ, S. R.; SLYE, R. E. Spatial variability in the interception of inclined rainfall by a tropical rainforest canopy. Selbyana, Sarasota, v. 13, p. 62 - 71, 1992.

INDÚSTRIA BRASILEIRA DE ÁRVORES (IBÁ). Relatório Anual 2016. São Paulo, SP, 2016. 96 p. Disponível em: <http://iba.org/pt/biblioteca-iba/publicacoes>. Acesso em: 11 nov. 2016.

LIMA, W. P. Interceptação da chuva em povoamentos de eucalipto e de pinheiro. IPEF, Piracicaba, n. 13, p. 7590, 1976.

MOURA, A. E. S. S.; CORREA, M. M.; SILVA, E. R.; LIMA, G. S.; SENA, J. R.; FIGUEIREDO, A. C. Precipitação efetiva nos períodos chuvoso e pouco chuvoso em um fragmento de Mata Atlântica, Recife — PE. Revista Brasileira de Recursos Hídricos, Porto Alegre, v. 17, n. 4, p. 7 - 16, 2012.

PRADA, S.; SEQUEIRA, M. M.; FIGUEIRA, C.; VASCONCELOS, R. Cloud water interception in the high altitude tree heath forest (Erica arborea L.) of Paul da Serra Massif (Madeira, Portugal). Hydrological Processes, Amsterdam, v. 26, n. 2, p. 202 - 212, 2012.

SARI, V; PAIVA, E. M. C. D.; PAIVA, J. B. D. Interceptação da chuva em diferentes formações florestais na região sul do Brasil. Revista Brasileira de Recursos Hídricos, Porto Alegre, v. 21, n. 1, p. 65 - 79, 2016.

SHINZATO, E. T.; TONELlO, K. C.; GASPAROTO, E. A. G.; VALENTE, R. O. A. Escoamento pelo tronco em diferentes povoamentos florestais na Floresta Nacional de Ipanema em Iperó, Brasil. Scientia Forestalis, Piracicaba, v. 39, n. 92, p. 395 - 402, 2011.

SOUZA, J. L. M.; FEZER, K. F.; GURSKI, B. C.; JERSZURKI, D.; PACHECHENIK, P. E. Soil water balance in different densities of Pinus taeda in Southern Brazil. Acta Scientiarum, Maringá, v. 38, n. 2, p. 265 - 271 , 2016.

TONELlO, K. C.; GASPAROTO, E. A. G.; SHINZATO, E. T.; VALENTE, R. O. A.; DIAS, H. C. T. Precipitação efetiva em diferentes formações florestais na Florestal Nacional de Ipanema. Revista Árvore, Viçosa, v. 38, n. 2, p. 383 - 390, 2014.

TREVISAN, R.; SALEMI, L. F.; GROPPO, J. D.; COSTA SILVA, R. W.; MARTINELLI, L. A.; MORAES, J. M. Dinâmica da água em uma microbacia com cobertura florestal de eucalipto localizada na Serra do Mar no Vale do Paraíba. Revista Brasileira de Recursos Hídricos, Porto Alegre, v. 17, n. 4, p. 207 - 216, 2012. 